\title{
Genetic Mapping of the Tsw Locus for Resistance to the Tospovirus Tomato spotted wilt virus in Capsicum spp. and Its Relationship to the Sw-5 Gene for Resistance to the Same Pathogen in Tomato
}

\author{
Molly Jahn, ${ }^{1}$ Ilan Paran, ${ }^{2}$ Katrin Hoffmann, ${ }^{3}$ Elaine R. Radwanski, ${ }^{1}$ Kevin D. Livingstone, ${ }^{1}$ \\ Rebecca C. Grube, ${ }^{1}$ Ester Aftergoot, ${ }^{2}$ Moshe Lapidot, ${ }^{4}$ and James Moyer ${ }^{3}$ \\ ${ }^{1}$ Department of Plant Breeding, Cornell University, Bradfield Hall, Ithaca, NY 14853 U.S.A.; ${ }^{2}$ Department of \\ Genetics and Plant Breeding, Agricultural Research Organization, The Volcani Center, P.O. Box 6, Bet \\ Dagan, 50250, Israel; ${ }^{3}$ Department of Plant Pathology, North Carolina State University, Raleigh 27695 \\ U.S.A.; ${ }^{4}$ Department of Virology, Agricultural Research Organization, The Volcani Center, P.O. Box 6, Bet \\ Dagan, 50250, Israel \\ Accepted 15 February 2000.
}

\begin{abstract}
The $T s w$ gene conferring dominant resistance to the Tospovirus Tomato spotted wilt virus (TSWV) in Capsicum spp. has been tagged with a random amplified polymorphic DNA marker and mapped to the distal portion of chromosome 10. No mapped homologues of $S w-5$, a phenotypically similar dominant TSWV resistance gene in tomato, map to this region in $C$. annuum, although a number of $S w-5$ homologues are found at corresponding positions in pepper and tomato. The relationship between $T s w$ and $S w-5$ was also examined through genetic studies of TSWV. The capacity of TSWV-A to overcome the $T_{s} w$ gene in pepper and the $S w-5$ gene in tomato maps to different TSWV genome segments. Therefore, despite phenotypic and genetic similarities of resistance in tomato and pepper, we infer that distinct viral gene products control the outcome of infection in plants carrying $S w-5$ and $T s w$, and that these loci do not appear to share a recent common evolutionary ancestor.
\end{abstract}

Additional keywords: comparative genetic mapping, $N x$, Solanaceae, viral genome reassortment.

Since the isolation and cloning of Pto in tomato, dramatic advances have occurred in our understanding of the molecular structure of dominant plant disease resistance $(R)$ genes involved in gene-for-gene interactions (Martin et al. 1993). Analyses of cloned $R$ genes and surrounding sequences have led to hypotheses concerning $R$ gene function during a host's response to pathogen infection, and how these sequences evolve (Meyers et al. 1998; Ronald 1998; Thomas et al. 1998). The precise details of the recognition of infection by the host, however, and the downstream events that result in resistance to infection, remain largely unknown (Innes 1998). The extent to which results from one host-pathogen interaction will illuminate mechanisms of resistance to other pathogens in that host or in other host species also remains unclear.

Corresponding author: Molly Jahn; E-mail: mmk9@ cornell.edu
Several lines of evidence suggest that many of the plant genes involved in mounting resistant responses may be widely conserved, both within a given host for different pathogens and even between host species. Striking sequence similarities have been noted among cloned $R$ genes that confer resistance to fungi, bacteria, nematodes, viruses, and insects in both monocotyledonous and dicotyledonous hosts (Bent et al. 1994; Milligan et al. 1998; Parker et al. 1997; Salmeron et al. 1996; Song et al. 1995; Rossi et al. 1998; Whitham et al. 1994). These similarities include well-defined motifs thought to be critical for gene function, such as nucleotide binding sites, leucine-rich repeats, and serine-threonine kinase-like domains (Ellis et al. 1999; Hammond-Kosack and Jones 1997; Thomas et al. 1997, 1998). Evidence that downstream events leading to resistance may also be conserved is suggested by expression of cloned transgenes in related plant species. When $N$, Pto, or $C f-9$ are expressed transgenically in some heterologous solanaceous hosts, resistance is observed in an otherwise susceptible plant (Hammond-Kosack et al. 1998; Loh and Martin 1995; Rommens et al. 1995; Thilmony et al. 1995; Whitham et al. 1996). This observation establishes that, at least in these cases, all necessary components of the resistance response are present and functional in the related host species.

Despite the noted sequence similarities, a systematic review of all known map positions for $R$ genes in three major solanaceous crop species (tomato, potato, and pepper) tied together by well-developed comparative genetic maps (Livingstone et al. 1999; Tanksley et al. 1992), revealed that resistance to the same pathogen never occurred in corresponding positions (Grube, Radwanski, and Jahn, in press). Only infrequent examples of limited positional correspondence of $R$ genes for the same general class of pathogen have been noted, e.g., among the grasses (Hartl et al. 1993; Schönfeld et al. 1996; Yu et al. 1996). In fact, the only case where resistance to the same pathogen has been attributed to evolutionarily related loci from different host species involves the $\mathrm{Hm}-\mathrm{l}$ locus (Multani et al. 1998), which is likely to be entirely unrelated to genefor-gene resistance (Johal and Briggs 1992). 
The apparent lack of correspondence of specificity among $R$ genes from related hosts involved in gene-for-gene interactions suggests that, among homologous loci, the molecular determinants of resistance specificity (recognition) may be evolving at a very different rate from the general resistance function (signal initiation). If this is the case, we might expect to see two types of consequences. First, if an $R$ gene became duplicated, the repeated sequences could diverge to give rise to new specificities, either to very closely related pathogens, as observed for the $C f$ loci in tomato and the $L$ locus in flax (Ellis et al. 1999; Thomas et al. 1998), or to pathogens belonging to diverse classes, as observed for Gpa-2 and $R x$ in potato (van der Voort et al. 1999). This divergence might occur very quickly, particularly if relatively few changes in nucleotide sequence could result in altered specificity, as appears to be the case. The second possible consequence is that host loci that are not closely related evolutionarily might still be involved in recognition of the same pathogen (although not necessarily the same pathogen gene products) and the same or very similar downstream events may be triggered, resulting in phenotypically similar resistance responses. In this case, the interactions of host and pathogen gene products that initially "trigger" resistant response may be dissimilar, but the consequences of that interaction may be similar or the same.

The Solanaceae are unique in the extent to which agriculturally important family members are infected by the same or very closely related plant pathogens, making it possible to examine the second of the two patterns of relationship described above. These include two important and well-characterized viruses for which $R$ genes have also been cloned, the Tobamovirus Tobacco mosaic virus (Whitham et al. 1994) and the Tospovirus Tomato spotted wilt virus (TSWV) (Brommenschenkel and Tanksley 1997; S. D. Tanksley, personal communication). This study focuses on resistance to TSWV, a widely distributed pathogen of $>800$ plant species including tomato and pepper (Capsicum spp.) (Edwardson and Christie 1997; Roselló et al. 1996). The tripartite, single-stranded genome of TSWV is composed of linear RNA molecules designated S, M, and L (see Munford et al. 1996 and references therein). Sequencing of these RNA components revealed that the L RNA encodes an RNA-dependent RNA polymerase, the M RNA encodes the precursor to the two glycoproteins found in the viral envelope and the putative movement protein, and the $\mathrm{S}$ molecule encodes the nucleocapsid protein and a nonstructural protein of unknown function. Strategies to map viral functions to genome segments via genome reassortment allow for rapid genetic analysis of the viral determinants of the host-pathogen interactions (Qiu et al. 1998).

Because of the economic importance of agricultural losses to TSWV, genetic resistance to this virus has been the focus of research for nearly seven decades. The first genetic studies of TSWV resistance in tomato reported five genes from two $L y$ copersicon spp., L. pimpinellifolium (Samuel et al. 1930) and L. esculentum (Holmes 1948). Two dominant genes were designated $S w-1^{a}$ and $S w-1^{b}$, and three recessive genes were designated $s w-2, s w-3$, and $s w-4$ (Finlay 1953). In all cases, these resistances were overcome quickly, and further work has not been pursued. The $S w-5$ gene, first identified in $L$. peruvianum, has proven more stable and less isolate specific than the previously identified factors (Stevens et al. 1992, Roselló et al. 1998). In plants carrying $S w-5$, no mosaic symptoms are observed after inoculation, although necrotic local lesions may appear on inoculated leaves. Rarely, this necrosis spreads through the plant, resulting in death. The $S w-5$ locus has been genetically mapped in tomato (Stevens et al. 1995); the cDNA has been cloned (Brommenschenkel and Tanksley 1997) and sequenced, and its homologues have been mapped in tomato (S. D. Tanksley, personal communication). Recently, another TSWV $R$ gene from $L$. peruvianum has been designated $S w-6$ (Roselló et al. 1998). The locus has not been mapped, but, in contrast to $S w-5, S w-6$ protects against a narrower range of viral isolates and confers only partial resistance to thrips inoculation (Roselló et al. 1998).

In Capsicum annuum, the only locus known to confer resistance to TSWV has been designated Tsw (Black et al. 1991; Boiteux et al. 1993). Tsw has been identified in C. chinense Jacq. USDA PI 152225, PI 159236, cv. Panca, and cv. 7204 (Boiteux 1995; Moury et al. 1997). Plants carrying $T s w$ often display no symptoms after mechanical inoculation, but occasionally they develop local necrotic lesions followed by premature abscission of the infected leaf (Boiteux 1995), similar to what is observed in tomato plants carrying the $S w-5$ gene. Furthermore, in preliminary studies, the isolate specificity of $T s w$ appeared to be similar to that of $S w-5$.

The first specific goal of this research was to map the $T s w$ locus for resistance to TSWV in pepper. Because of the apparent similarities between resistant responses to TSWV mediated by $S w-5$ in tomato and $T s w$ in pepper, our next goal was to investigate the comparative genetics of resistance to TSWV in order to shed light on the evolutionary and mechanistic relationship between these solanaceous $R$ genes.

\section{RESULTS}

\section{RAPD marker linked to $T s w$.}

To efficiently screen for polymorphic markers linked to TSWV resistance, an inbred backcross population was developed between $C$. chinense PI 152225 and TSWV-susceptible C. апnuиm genotypes cvs. Cuby and Spartacus. After four backcrosses to the respective susceptible parents to minimize polymorphism unlinked to TSWV, one TSWV-resistant $\mathrm{BC}_{4} \mathrm{~F}_{1}$ plant in each genetic background was selected and DNA was extracted to compare with the susceptible parental genotypes. Out of 400 randomly amplified polymorphic DNA (RAPD) primers screened on these genotypes, five (Q-06, Q-15, O-05, $\mathrm{N}-14, \mathrm{~N}-20$ ) amplified products polymorphic between the resistant backcross individuals and the susceptible recurrent parents. The amplified products for these primers were scored in additional resistant and susceptible $\mathrm{BC}_{4} \mathrm{~F}_{1}$ plants (10 each). Only one of these amplification products, a 270-bp fragment (Q-06 270 ) amplified by Q-06 (GAGCGCCTTG), cosegregated with resistance (Fig. 1).

DNA samples from a larger $(C$. annuum $\mathrm{cv}$. Maor $\times$ PI 152225) $\mathrm{BC}_{4} \mathrm{~F}_{1}$ population of 116 plants evaluated for TSWV resistance were amplified with Q-06 to determine the genetic distance between $T s w$ and Q-06 270 . Segregation observed for TSWV resistance was consistent with a single-gene model (63:53 resistant: susceptible, $\chi^{2}$ for $1: 1=0.86, P=0.35$ ). Of the $116 \mathrm{BC}_{4} \mathrm{~F}_{1}$ plants, four were recombinants between $T s w$ and Q- $06_{270}$, indicating the two loci are $3.45 \mathrm{cM}$ (Kosambi) apart. 


\section{C. chinense PI 159234 contains $Q-06_{270}$ and is resistant to TSWV.}

To place the locus defined by the Q-06 270 polymorphism on a comparative genetic map of Capsicum spp., and to obtain evidence of linkage between Q- $06_{270}$ and $T s w$ in an independent population, we mapped $\mathrm{Q}-06_{270}$ and resistance to TSWV in the population used by Livingstone et al. (1999). This population is the basis of the only well-developed comparative genetic map in pepper. First, it was necessary to establish that the Q-06 primer amplified a fragment in the $C$. chinense parent of this population, PI 159234, that was identical in size to that found in PI 152225 (Fig. 2). Second, it was necessary to establish that the parents of this comparative mapping population contrasted with respect to response to TSWV; thus, an inbred line of $C$. chinense PI 159234 and the $C$. annuum parent, cv. NuMex RNaky, was screened with TSWV. Plants from PI 159234 uniformly fell into phenotypic classes judged resistant. They either remained asymptomatic or developed local or more extensive necrosis that occasionally killed the plant. The phenotypic response even within highly inbred lines of PI 159234 was considerably more variable than for any other resistant genotype screened (data not shown); however, in no case was the typical susceptible reaction, mosaic without necrosis, observed on these plants. In contrast, both resistant (PI 152225) and susceptible check plants including the genotype NuMex RNaky inoculated at the same time were uniformly resistant (asymptomatic) or susceptible (systemic mosaic symptoms), respectively. This confirmed that PI 159234 was resistant to TSWV according to the criteria of Moury et al. (1998).

\section{Relationship of TSWV resistance in PI 152225 and PI 159234.}

Previous work has not revealed distinguishable resistance alleles at the $T s w$ locus in C. chinense (Boiteux 1995), nor have additional resistance loci been reported in Capsicum spp. (Boiteux et al. 1993; Boiteux 1995; Moury et al. 1997). While definitive proof of allelism is not possible for dominant genes via genetic complementation analysis, two lines of evidence were obtained regarding the relationship of TSWV resistance

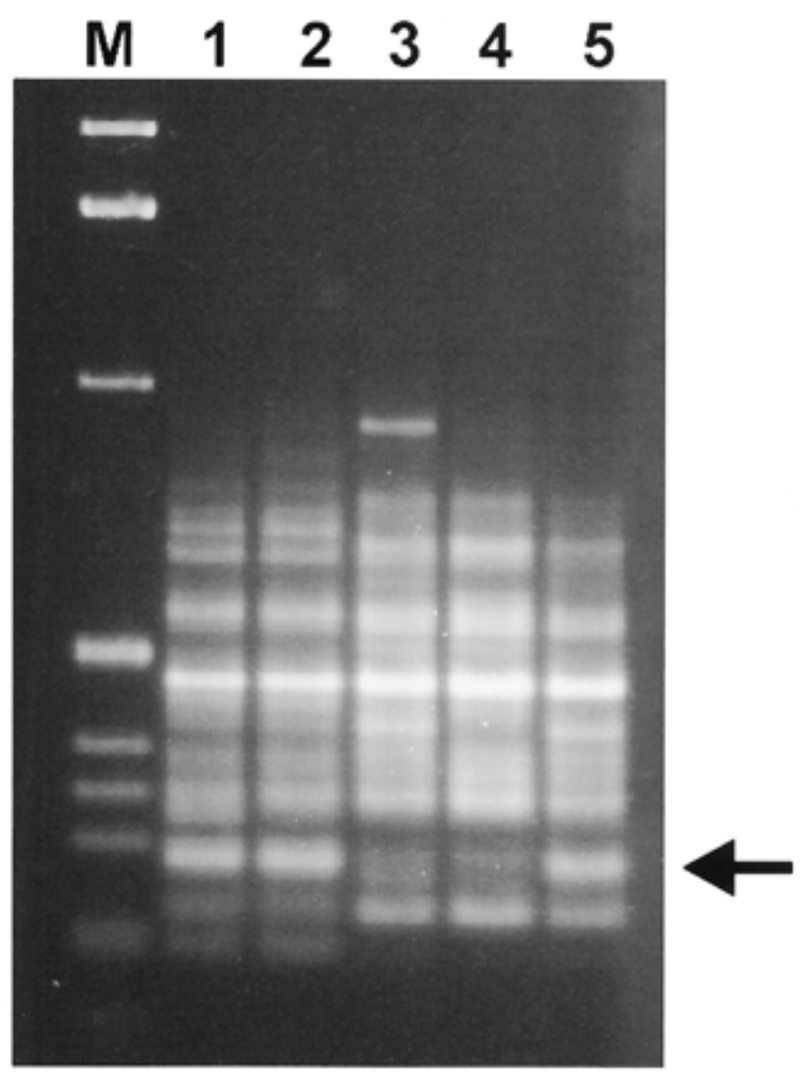

Fig. 2. Amplification of DNA extracted from Capsicum chinense PI 152225 (lane 1), C. chinense PI 159234 (lane 2), C. annuum cv. Maor (lane 3), C. annuum cv. NuMex RNaky (lane 4), and one $\mathrm{BC}_{4} \mathrm{~F}_{1}$ plant resistant to Tomato spotted wilt virus (lane 5) with primer Q-06 (Operon Technologies, Alameda, CA). The 270-bp amplification product (arrow) shown to cosegregate with resistance from $C$. chinense PI 152225 is also seen in the resistant $C$. chinense genotype used in the mapping population of Livingstone et al. (1999) and a resistant (Maor $\times$ PI 152225) $\mathrm{BC}_{4} \mathrm{~F}_{1}$ plant and is absent in both susceptible $C$. annuum parents. Lane M contains a 1-kb ladder.

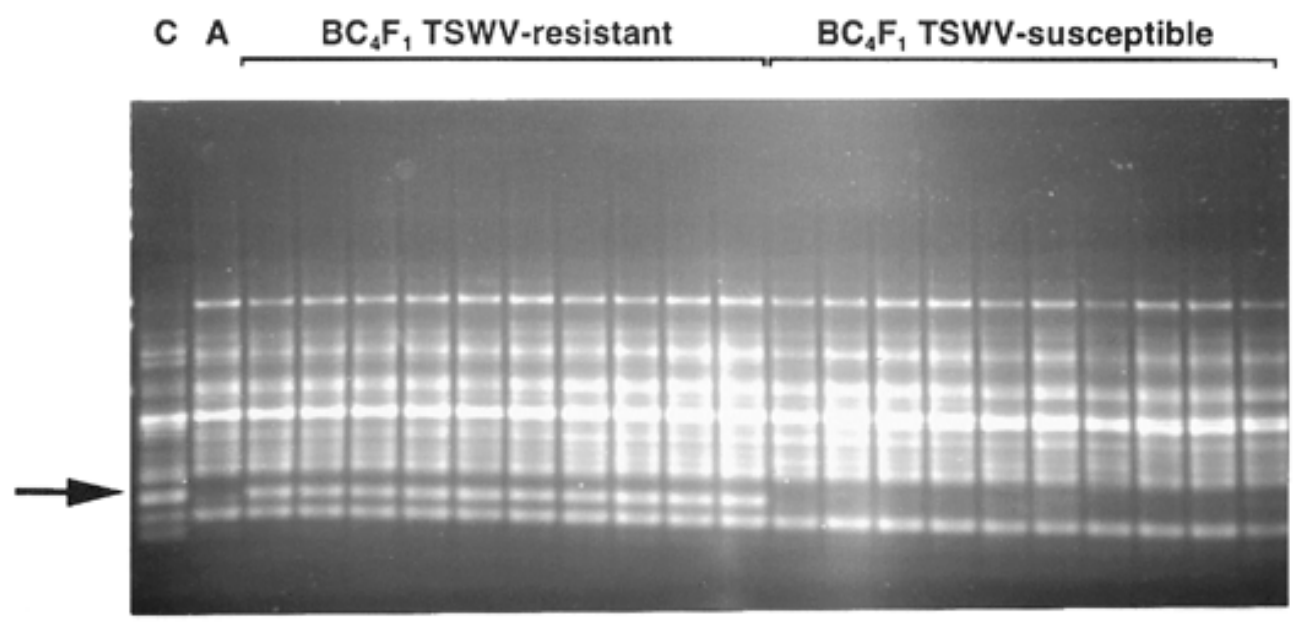

Fig. 1. Cosegregation of resistance to Tomato spotted wilt virus (TSWV) in Capsicum spp. with the 270-bp amplification product from primer Q-06 (Operon Technologies, Alameda, CA). Q- $06_{270}$ (arrow) is present in TSWV-resistant C. chinense PI 152225 (C) and 10 resistant $\mathrm{BC}_{4} \mathrm{~F}_{1}$ plants, but absent in TSWV-susceptible $C$. annuиm cv. Maor (A) and 10 susceptible $\mathrm{BC}_{4} \mathrm{~F}_{1}$ plants. 
in PI 159234 and PI 152225, to rule out the possibility that two different genes with similar inheritance and phenotype exist in pepper for resistance to TSWV, as has been observed for the potyviruses (Grube, Blauth, et al., in press; Kyle and Palloix 1997). First, >200 (PI $159234 \times$ PI 152225) $\mathrm{F}_{2}$ plants were inoculated with TSWV, and no susceptible segregants were recovered. Therefore, if resistance in PI 152225 and PI 159234 is due to alleles at different loci, these loci must be tightly linked. Also, the two PIs showed identical patterns of susceptibility and resistance when screened with a panel of TSWV isolates, including those known to break resistance in pepper and tomato (data not shown).

\section{Mapping of Q-06 270 and $T s w$ on a comparative genetic map.}

A precise estimate of the linkage intensity between $T s w$ and Q- $06_{270}$ was established in the $\mathrm{BC}_{4}$ population described above; however, a detailed comparative genetic map is not available for this population. Therefore, segregation at the locus defined by the Q-06 polymorphism was mapped in the interspecific population of Livingstone et al. (1999). Segregation of the Q-06 270 band in 64 (C. annuum cv. NuMex RNaky $\times C$. chinense PI 159234) $\mathrm{F}_{2}$ plants indicated that this locus mapped to a framework position on linkage group $10(\mathrm{Lg} 10)$ of Livingstone et al. (1999) within the interval defined by the framework markers CT57 and CD73. Q-06 270 is located 9.1 cM from CT57 and $11.6 \mathrm{cM}$ from CD73 (Fig. 3) and is linked at $2.1 \mathrm{cM}$ to TG420 (LOD 8.92).

The $\mathrm{F}_{2} T s w$ genotypes were inferred from segregation of TSWV resistance in $\mathrm{F}_{3}$ families derived from $\mathrm{F}_{2}$ plants used to construct the Livingstone et al. (1999) map. Local necrotic lesions were first visible on resistant check genotypes and some but not all $\mathrm{F}_{3}$ plants at 4 days post inoculation (dpi). Mosaic became evident on all plants of the susceptible check cultivar (NuMex RNaky) and was clearly developed on some $\mathrm{F}_{3}$ plants by 10 dpi. Resistance was scored as absence of any local or systemic symptoms, or local or systemic necrosis without mosaic or ringspots. Susceptibility was indicated by

\section{LG 10}

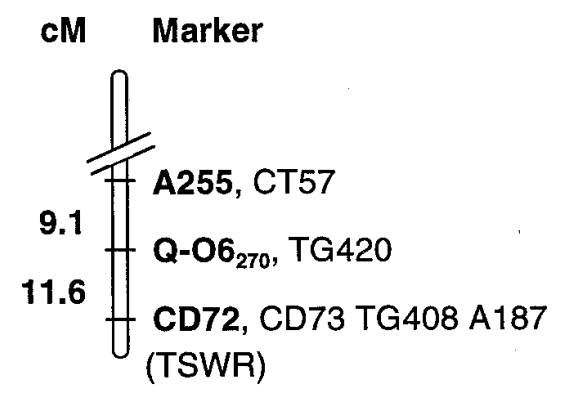

Fig. 3. Linkage of Tomato spotted wilt virus (TSWV) resistance and Q$06_{270}$ with distal markers on Capsicum spp. Lg 10 (map based on the $\mathrm{F}_{2}$ population from $C$. annuиm cv. NuMex RNaky $\times C$. chinense PI 159234; Livingstone et al. 1999; see Figure 5). Markers in bold at tick marks indicate framework loci established at LOD $\geq 3.0$, and markers after the commas are linked $(<5 \mathrm{cM})$ to framework markers. Resistance to TSWV (TSWR) scored on a subset of $F_{3}$ families from the mapping population established that $T s w$ grouped with this set of markers. chlorotic ringspots that developed into systemic mosaic on leaves, necrotic lesions accompanied by mosaic on uninoculated leaves and stems, necrotic growing tips, fruit with large necrotic areas, and stunting. In some cases, it was difficult to determine whether the extensive necrosis was accompanied by mosaic as opposed to yellowing associated with plant death. Five classes were scored: systemic mosaic; systemic mosaic with necrosis; systemic necrosis; local lesions; and, no symptoms.

The position of the resistance phenotype could not be located more precisely than an extreme distal position on $\mathrm{Lg} 10$. The first two classes were scored as susceptible and the last two classes were scored as resistant; however, it was unclear whether the families in the phenotypic classes showing systemic necrosis should be grouped with the susceptible or resistant class. All possibilities were tried and the only linkage obtained was to $\operatorname{Lg} 10$ when the systemic necrotic classes were scored as susceptible. Pairwise linkages between the resistance phenotype and the following markers were observed: A187 (LOD 4.17, $14.71 \mathrm{cM}$ ), CD72 (LOD 3.29, $20.5 \mathrm{cM}$ ) TG420 (LOD 2.95, $19.5 \mathrm{cM}$ ), and TG408 (LOD 2.83, 20.4 cM) (Fig. 3). All these markers are linked to $\mathrm{Q}-06_{270}$ and identify a single region for the position of $T s w$ in the pepper genome. As expected because of difficulties with phenotypic analysis in this population, distances between these markers and $T s w$ are not consistent with the more accurate estimates of linkage between $\mathrm{Q}-06_{270}$ and $T s w$ in the tagging population, and represent a much less accurate placement for $T s w$ than the position of Q- $-06_{270}$ on the comparative map.

\section{Sw-5 homologues do not cosegregate with TSWV resistance in pepper.}

To examine whether there is any detectable relationship between the $S w-5$ locus in tomato and $T s w$ in pepper, pepper homologues of the $S w-5$ cDNA and CT220, a tomato cDNA clone tightly linked to $S w-5$ in at least one tomato mapping population (Brommenschenkel and Tanksley 1997), were also mapped in Capsicum spp. CT220 detects only two or three bands in each of 12 different restriction endonuclease digests of the Capsicum spp. parental DNA (data not shown). In contrast, even under stringent hybridization conditions, the $S w-5$ cDNA clone hybridizes to numerous pepper genomic DNA restriction fragment-length polymorphisms (RFLPs) (Fig. 4). The percentage of bands that are monomorphic between the parents ranges from approximately $30 \%$ (3/9 C. annuum; $3 / 8$ C. chinense) for $\mathrm{Xba \textrm {I }}$ to $100 \%$ (5/5 for both parents) for BamHI.

Analysis of the segregation of the polymorphic bands to which $S w-5$ cDNA hybridized (Sw-5 RFLPs) demonstrated that three Sw-5 RFLPs cosegregated with the framework marker, CT220, at the end of pepper Lg 3, and two other Sw-5 RFLPs mapped to nearby intervals. Two additional RFLPs were found to group loosely with Lgs 5 and 7, but could not be localized definitively on the map. Every pepper homologue of $S w-5$ that can be mapped resides on a different pepper linkage group than Q- $06_{270}$ and $T s w(\mathrm{Lg} 10)$ (Fig. 5). While no $S w$-5-related sequences were found in the same linkage group as $T s w$ and Q-06 270 , several of the $S w-5$ homologues in pepper do correspond precisely to locations for $S w-5$ and $S w-5$ homologues in tomato (S. D. Tanksley, personal communication), as shown in Figure 5. 
Mutations that overcome $S w-5$ and $T s w$ map

to different TSWV genome segments.

TSWV-A, a strain capable of overcoming resistance in tomato controlled by $S w-5$, has been isolated and characterized (Cho et al. 1996). When a susceptible host plant such as tobacco is infected with TSWV-A and TSWV-D, a strain suppressed by both $T s w$ and $S w-5$, reassorted viral progenies can be recovered that allow identification of the genome segment responsible for the resistance-breaking character. Using this method, Hoffmann et al. have established that the M RNA from TSWV-A $\left(\mathrm{M}_{\mathrm{A}}\right)$ determines the $S w-5$ resistance-breaking character (K. Hoffmann, W. Qiu, and J. Moyer, unpublished). When peppers carrying $T s w$ were inoculated with TSWV-A, this strain also proved capable of overcoming resistance in peppers. When the same panel of reassortants used in the tomato study were inoculated onto pepper lines with and without the $T s w$ gene, the $T s w$ resistance-breaking character mapped to the $S_{\mathrm{A}}$ RNA, indicating that the ability to overcome $T s w$ and $S w-5$ maps to different TSWV genome segments (Table 1). Therefore, despite the phenotypic similarity of the localizing necrotic responses to TSWV controlled by dominant $R$ genes occurring in closely related host species, these results indicate that distinct viral genes or gene products control the outcome of infection in resistant tomato and pepper plants.

\section{DISCUSSION}

The Tsw locus in Capsicum spp. has been mapped to chromosome 10 in the vicinity of two very tightly linked, dominant, potyvirus $R$ genes, $P v r 4$ and $P v r 7$ (Grube, Blauth, et al., in press). Clusters of disease resistance genes of both related and unrelated specificity have been observed in many plant species (Michelmore and Meyers 1998 and references therein), but this grouping is the first well-defined cluster of dominant $R$ genes in pepper. Q- $06_{270}$, the most reliable indicator of the position for $T s w$, is 15 to $16 \mathrm{cM}$ proximal to $P v r 4$ and $P v r 7$, but still well within the $30-\mathrm{cM}$ limit defined by Michelmore and Meyers (1998), who suggested that the clustering of disease $R$ genes may be a cause and/or consequence of evolutionary processes at $R$ gene loci (e.g., Parniske and Jones 1999).

With a map position for $T s w$ established, the possibility of evolutionary relationships between $T s w$ and other solanaceous $R$ genes with similar phenotype and specificity, including $S w$ 5 , could be explored via comparative genetic mapping. Unique positions for $S w-5$ homologues with no mapped counterpart in the other species occurred in both pepper and tomato, but at least three pepper $S w-5$ homologues occurred at positions that did correspond to $S w-5$ homologues in tomato. No $S w-5$ homologues were mapped to pepper chromosome 10 .

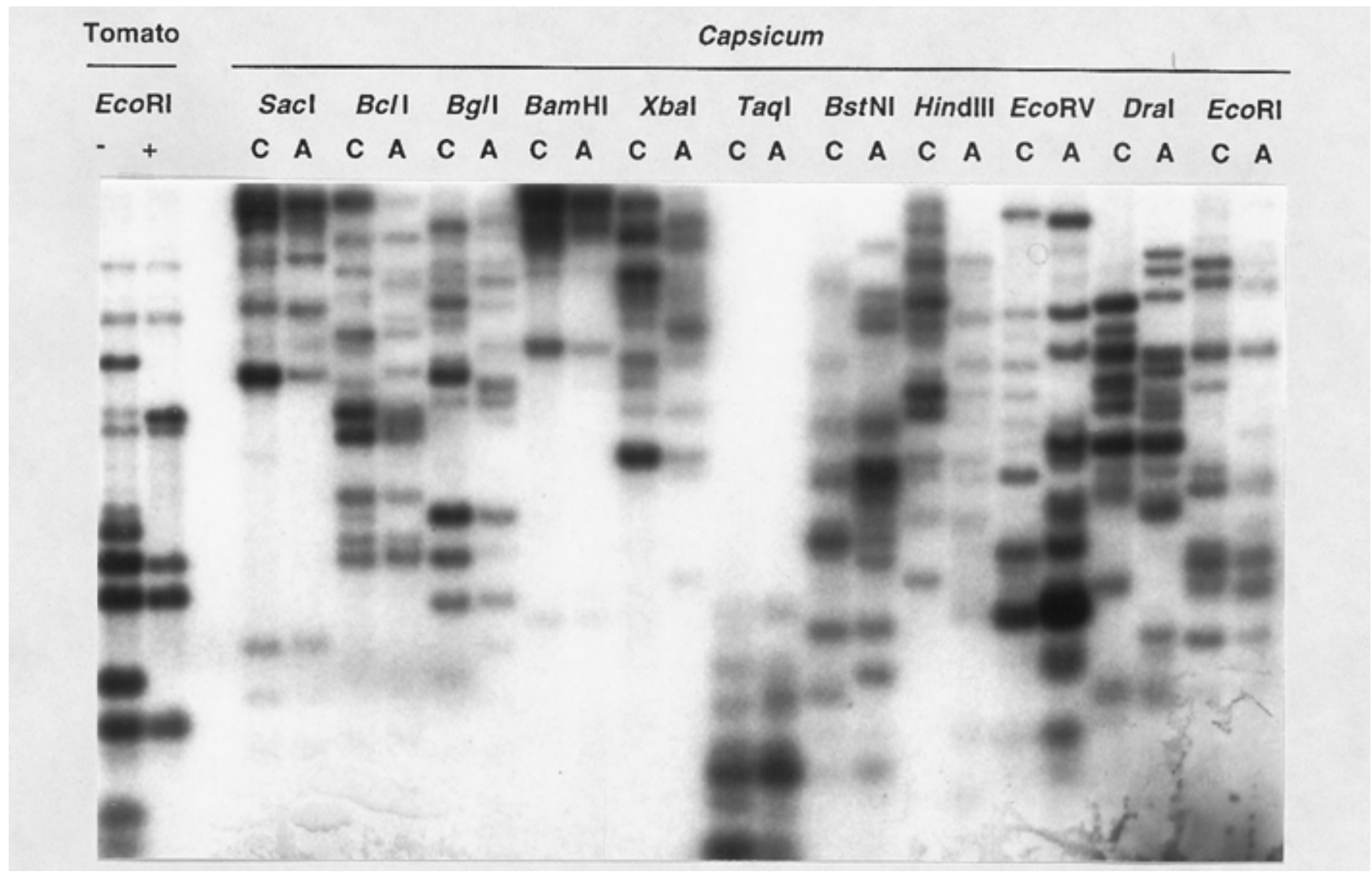

Fig. 4. Multiple $S w-5$ homologues in Capsicum spp. and tomato. Autoradiogram of gel blots containing genomic DNA from $C$. annuum cv. NuMex RNaky (A lanes) and C. chinense PI 159234 (C lanes) digested with 11 restriction endonucleases and probed with the $S w-5$ cDNA. Lanes at left contain DNA from tomato near-isogenic lines for $S w-5$ : TA209, susceptible (-) and TA277, resistant (+). 
While this result is consistent with the hypothesis that $S w-5$ and $T s w$ are not related evolutionarily, it could also be explained either by failure to map every $S w-5$ homologue in the pepper genome due to lack of polymorphism, or by incomplete knowledge of all the TSWV $R$ genes in pepper and tomato. Along these lines, a TSWV $R$ gene from $L$. peruvianum has recently been designated $S w-6$ (Roselló et al. 1998). The locus has not been mapped, but several phenotypic features appear to distinguish it from $T s w$ in pepper, as is also the case for the other $S w$ or $s w$ genes in tomato. $S w-6$ protects against a narrower range of isolates than $T s w$ or $S w-5$, and confers only partial resistance to thrips inoculation (Roselló et al. 1998). None of the other reported TSWV $R$ genes in tomato appear to share any mechanistic similarity with $T s w$, nor do they appear to confer resistance to the same range of viral isolates.

As described above, an inherent limitation of mapping analyses is that it is often impossible to establish a definitive position for every gene homologue that occurs in a genome; however, evidence from genetic analysis of the resistancebreaking character in the virus further supports our conclusion that $T s w$ and $S w-5$ are not recently derived from a common evolutionary ancestor. Although TSWV-A is capable of overcoming both $S w-5$ and $T s w$, the genome reassortment experiments demonstrated that different viral genes overcome the two host $R$ genes. Identification of the specific sequences in viral genes that alter the outcome of infection will shed light on which TSWV gene products are critical determinants in these interactions and will also define useful systems for detailed molecular analyses of resistance mechanisms.

Our results suggest there may not be a direct evolutionary relationship between these genes for resistance to TSWV in pepper and tomato. This is similar to results obtained thus far in the Solanaceae for every resistance where a comparative genetic analysis is possible. Previous studies have shown that monogenic dominant, phenotypically similar resistance to TMV in tomato, tobacco, and pepper appears to be unrelated (Grube, Radwinski, et al., in press; Ohmori et al. 1998). This conclusion with regard to TMV resistance was confirmed, at least in part, by studies of resistance-breaking mutations in the virus (Meshi et al. 1988, 1989; Padgett and Beachy 1993; Watanabe et al. 1987). Likewise for potyvirus resistance in potato: $R y$ and $R a$, the dominant genes in potato for resistance to the potyviruses Potato potyvirus $Y$ (PVY) and Potato poty-

Fig. 5. Comparative map showing positions of Tomato spotted wilt virus (TSWV) resistance loci and relevant $S w-5$ homologues in tomato and Capsicum spp. A, Map showing relationship between $S w-5, S w-5$ homologues in tomato on chromosome 9 mapped by S. H. Brommenschenkel, A. Frary, A. Frary, and S. D. Tanksley (personal communication) and corresponding regions in Capsicum spp. based on Livingstone et al. (1999). Tick marks on the chromosomes are framework positions for respective maps (framework positions are given on the tomato map only for markers mapped in pepper); lines connecting the two chromosomes show relative positions of presumed orthologous loci. Phenotypically defined TSWV resistance locus in tomato, $S w 5$, is indicated by asterisk. Other restriction fragment-length polymorphisms detected by the $S w-5$ cDNA in both species are denoted as Sw5-H; minimum number of fragments mapped to that position is given in brackets. Markers in parentheses mapped between framework markers. B, Map showing relationship between Q-06 270 in Capsicum spp. and corresponding regions in tomato. No mapped $S w-5$ homologues in tomato were found in a position that corresponded to the $T s w$ locus in pepper. virus $A$, do not appear to be evolutionarily related to dominant genes in pepper, $P v r 4$ and $P v r 7$, for resistance to PVY and Pepper mottle virus (Grube, Blauth, et al., in press). Finally, dominant genes defined thus far in tomato and potato for resistance to Phytophthora infestans map to unrelated regions of the host genomes (El-Kharbotly et al. 1994, 1996; Li et al. 1998; Meksem et al. 1995; Moreau et al. 1998; Pierce 1971).

We and others have thus far failed to uncover any example of preserved resistance specificity at $R$ loci in corresponding

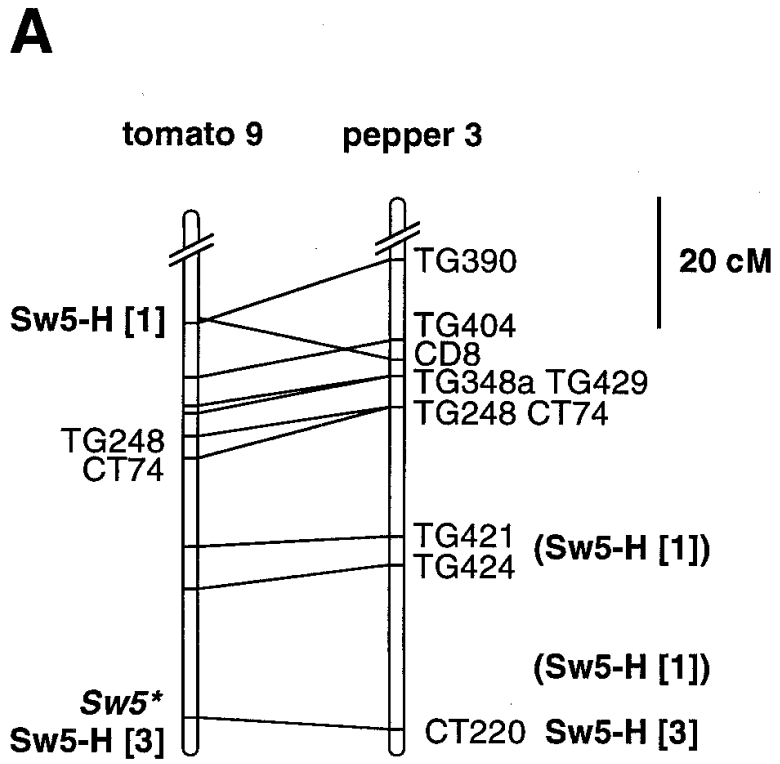

B

tomato 10 pepper 10

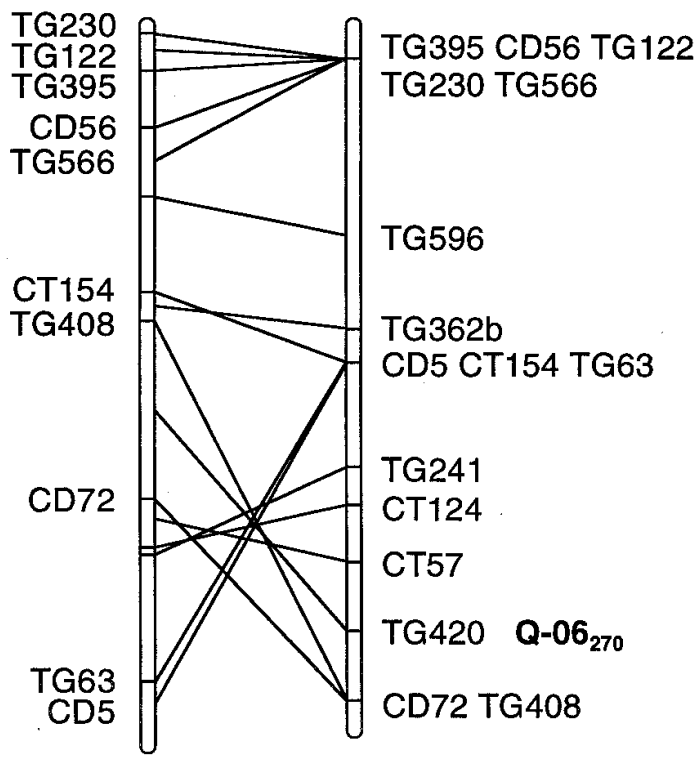


positions, even between closely related hosts (Grube, Radwinski, et al., in press); however, the map position for one pepper $S w-5$ homologue shows an intriguing parallel with recent results from potato. Hehl et al. (1999) observed that a homologue of the $N$ gene from tobacco for resistance to TMV colocalized precisely with dominant resistance to the fungus Synchytrium endobioticum. Similarly, one pepper $S w-5$ homologue mapped approximately $20 \mathrm{cM}$ proximal to the cluster of $S w-5$ homologues that occur in both pepper and tomato at the position of the $S w-5$ locus in tomato (Fig. 5A). This $S w-5$ homologue cosegregated precisely with TG424 in the population of Livingstone et al. (1999), except for two plants with an ambiguous genotype for TG424. In potato, the $N x_{p h u}$ gene, a dominant gene for necrotic localizing resistance to the Potexvirus Potato virus $X$, also occurs at TG424 (Tommiska et al. 1998). $S w-5$ homologues have not been mapped in potato, but if cosegregation of a $S w-5$ homologue in Solanum spp. and $N x_{p h u}$ were to be observed, this would provide evidence suggesting a relationship between these loci. Sequence comparison between $S w-5$ and $N x_{p h u}$, when possible, may reveal that these genes are homologous and that their pathogen specificity has diverged, perhaps as a result of small changes in sequence localized to particular domains. If $S w-5$ and $N x_{p h u}$ are homologues, this may indicate that the downstream consequences of the interaction between different hosts and different plant pathogens may be very similar.

In summary, a map position for the $T s w$ locus for resistance to TSWV in Capsicum spp. has been established and a tightly linked molecular marker has been identified that should facilitate efforts to develop tools for marker-assisted selection of this resistance. Further, we have shown that $T s w$ and $S w-5$ do not appear to interact with the virus in the same way, and it is unlikely that they are recently derived from a common evolutionary ancestor. Despite these differences, it is still possible that gross phenotypic similarities are observed because the
$T s w$ and $S w-5$ gene products interact with the same or essentially similar downstream processes that result in expression of resistance. The co-localization of a $S w-5$ homologue with a marker tightly linked to the $N x$ locus in Solanum spp. suggests the possibility of a relationship between $S w-5$ and the resistance allele at this locus. If these $R$ genes prove to be homologous, sequence comparisons should reveal the molecular differences that account for functional divergence with respect to specificity, thus defining further hypotheses regarding the identities of and relationships among molecules involved in perceiving infection and producing resistant responses in plants.

\section{MATERIALS AND METHODS}

\section{Plant germplasm and genetic populations.}

To create suitable populations for tagging $T s w, C$. chinense PI 152225 (USDA) was crossed to a susceptible bell, cv. Maor, and backcrossed four times to each of two susceptible bell $C$. annuum parents, cvs. Cuby and Spartacus. A second population, (C. annuum cv. NuMex RNaky $\times$ PI 159234) $\mathrm{F}_{2}$, was used to place a marker identified in the tagging experiments on a comparative genetic map of pepper (Livingstone et al. 1999). To determine the relationship between TSWV resistance in PI 152225 and PI 159234, they were intercrossed and $F_{2}$ seed was harvested from individual $F_{1}$ plants. Two hundred (PI $159234 \times$ PI 152225) $\mathrm{F}_{2}$ plants were screened with TSWV to determine whether any segregation for susceptibility was observed.

\section{TSWV screening.}

TSWV strain BR-01 (Antignus et al. 1997) was maintained on tomato plants in the greenhouse at The Volcani Center, increased on Nicotiana tabacum cv. Xanthi prior to transfer to pepper, and used to inoculate (Maor $\times$ PI 152225) $\mathrm{BC}_{4} \mathrm{~F}_{1}$

Table 1. Bioassay of Tomato spotted wilt virus (TSWV) on resistant and susceptible pepper genotypes

\begin{tabular}{|c|c|c|c|c|c|c|c|c|c|c|c|c|}
\hline \multirow[b]{3}{*}{ TSWV genotype ${ }^{b}$} & \multicolumn{4}{|c|}{7 days post inoculation } & \multicolumn{4}{|c|}{14 days post inoculation } & \multicolumn{4}{|c|}{21 days post inoculation } \\
\hline & \multicolumn{2}{|c|}{ Susceptible $^{a}$} & \multicolumn{2}{|c|}{ Resistant } & \multicolumn{2}{|c|}{ Susceptible } & \multicolumn{2}{|c|}{ Resistant } & \multicolumn{2}{|c|}{ Susceptible } & \multicolumn{2}{|c|}{ Resistant } \\
\hline & $\mathbf{I}^{\mathbf{c}}$ & $\mathbf{U}$ & I & $\mathbf{U}$ & $\mathbf{I}$ & $\mathbf{U}$ & $\mathbf{I}$ & $\mathbf{U}$ & $\mathbf{I}$ & $\mathbf{U}$ & $\mathbf{I}$ & $\mathbf{U}$ \\
\hline \multirow{2}{*}{$\mathrm{L}_{\mathrm{D}} \mathrm{M}_{\mathrm{D}} \mathrm{S}_{\mathrm{D}}$} & $4 / 4 \mathrm{cs}^{\mathrm{d}}$ & $1 / 4$ & $3 / 411$ & $0 / 4$ & $4 / 4 \mathrm{cs}$ & $4 / 4$ & $4 / 411$ & $0 / 4$ & $4 / 4 \mathrm{cs}$ & $4 / 4(1)$ & $4 / 411$ & $0 / 4$ \\
\hline & $5 / 5 \mathrm{cs}$ & $0 / 5$ & $4 / 511$ & $0 / 5$ & $5 / 5 \mathrm{cs}$ & $5 / 5$ & $5 / 511$ & $1 / 5$ & $5 / 5 \mathrm{cs}$ & $5 / 5$ & $5 / 511$ & $1 / 5$ \\
\hline \multirow{2}{*}{$\mathbf{L}_{\mathbf{A}} \mathbf{M}_{\mathbf{A}} \mathbf{S}_{\mathbf{A}}{ }^{\mathrm{e}}$} & $4 / 4 \mathrm{cs}$ & $2 / 4$ & $4 / 4 \mathrm{cs}$ & $2 / 4$ & $4 / 4 \mathrm{cs}$ & $4 / 4$ & $4 / 4 n s^{f}$ & 4/4 (3) & $4 / 4 \mathrm{cs}$ & $4 / 4$ & $4 / 4 n s$ & $4 / 4(3)$ \\
\hline & $5 / 5 \mathrm{cs}$ & $0 / 5$ & $5 / 5 \mathrm{~ns}$ & $0 / 5$ & $5 / 5 \mathrm{cs}$ & $5 / 5$ & $5 / 5 \mathrm{~ns}$ & $5 / 5$ & $5 / 5 \mathrm{cs}$ & $5 / 5$ & $5 / 5 \mathrm{~ns}$ & $5 / 5(5)$ \\
\hline \multirow{2}{*}{$\mathbf{L}_{\mathbf{D}} \mathbf{M}_{\mathbf{A}} \mathbf{S}_{\mathbf{A}}$} & $4 / 4 \mathrm{cs}$ & $3 / 4$ & $4 / 4 n s$ & $4 / 4$ & $4 / 4 \mathrm{cs}$ & $4 / 4$ & $4 / 4 n s$ & $4 / 4(4)$ & $4 / 4 \mathrm{cs}$ & $4 / 4$ & $4 / 4 n s$ & $4 / 4(4)$ \\
\hline & $5 / 5 \mathrm{cs}, \mathrm{ns}$ & $0 / 5$ & $5 / 5 \mathrm{~ns}$ & $0 / 5$ & $5 / 5 \mathrm{~ns}$ & $5 / 5$ & $5 / 5 n s$ & $5 / 5(4)$ & $5 / 5 n s$ & $5 / 5$ & $5 / 5 n s$ & $5 / 5(5)$ \\
\hline \multirow[t]{2}{*}{$\mathbf{L}_{\mathbf{A}} \mathbf{M}_{\mathbf{D}} \mathbf{S}_{\mathrm{A}}$} & $4 / 4 \mathrm{cs}$ & $0 / 4$ & $4 / 4 \mathrm{cs}$ & $0 / 4$ & $4 / 4 \mathrm{cs}$ & $4 / 4$ & $4 / 4 \mathrm{cs}$ & $4 / 4$ & $4 / 4 \mathrm{cs}$ & $4 / 4$ & $4 / 4 \mathrm{cs}$ & $4 / 4$ \\
\hline & $5 / 5 \mathrm{cs}, \mathrm{ns}$ & $0 / 5$ & $5 / 5 \mathrm{cs}, \mathrm{ns}$ & $0 / 5$ & $5 / 5 \mathrm{~ns}$ & $5 / 5$ & $5 / 5 \mathrm{cs}$ & $5 / 5$ & $5 / 5 \mathrm{~ns}$ & $5 / 5$ & $5 / 5 \mathrm{cs}$ & $5 / 5(1)$ \\
\hline \multirow{2}{*}{$\mathrm{L}_{\mathrm{A}} \mathrm{M}_{\mathrm{D}} \mathrm{S}_{\mathrm{D}}$} & $4 / 4 \mathrm{cs}$ & $0 / 4$ & 4/411 & $0 / 4$ & $4 / 4 \mathrm{cs}$ & $4 / 4$ & 4/411 & $0 / 4$ & $4 / 4 \mathrm{cs}$ & $4 / 4(3 / 4)$ & 4/411 & $0 / 4$ \\
\hline & $5 / 5 \mathrm{cs}$ & $0 / 5$ & $5 / 511$ & $0 / 5$ & $5 / 5 \mathrm{cs}$ & $5 / 5$ & $5 / 511$ & $1 / 5$ & $5 / 5 \mathrm{cs}$ & $5 / 5$ & $5 / 511$ & $1 / 5$ \\
\hline \multirow{2}{*}{$\mathbf{L}_{\mathbf{D}} \mathbf{M}_{\mathbf{D}} \mathbf{S}_{\mathrm{A}}$} & $4 / 4 \mathrm{cs}$ & $0 / 4$ & $4 / 4 \mathrm{cs}$ & $1 / 4$ & $4 / 4 \mathrm{cs}$ & $4 / 4$ & $4 / 4 \mathrm{cs}$ & 4/4 (3) & $4 / 4 \mathrm{cs}$ & $4 / 4$ & $4 / 4 \mathrm{cs}$ & $4 / 4(4)$ \\
\hline & $5 / 5 \mathrm{cs}$ & $0 / 5$ & $5 / 5 \mathrm{cs}, \mathrm{ns}$ & $0 / 5$ & $5 / 5 \mathrm{cs}$ & $5 / 5$ & $5 / 5 \mathrm{~ns}$ & $5 / 5$ & $5 / 5 \mathrm{cs}$ & $5 / 5$ & $5 / 5 \mathrm{~ns}$ & $5 / 5(5)$ \\
\hline \multirow[t]{2}{*}{$\mathrm{L}_{\mathrm{A}} \mathrm{M}_{\mathrm{A}} \mathrm{S}_{\mathrm{D}}$} & $4 / 4 \mathrm{cs}$ & $1 / 4$ & 4/411 & $0 / 4$ & $4 / 4 \mathrm{cs}$ & $4 / 4$ & $4 / 411$ & $1 / 4$ & $4 / 4 \mathrm{cs}$ & $4 / 4$ & $4 / 411$ & $1 / 4$ \\
\hline & $5 / 5 \mathrm{cs}$ & $0 / 5$ & $5 / 511$ & $0 / 5$ & $5 / 5 \mathrm{cs}$ & $5 / 5$ & $5 / 511$ & $1 / 5$ & $5 / 5 \mathrm{cs}$ & $5 / 5$ & $5 / 511$ & $1 / 5$ \\
\hline \multirow{2}{*}{$\mathrm{L}_{\mathrm{D}} \mathrm{M}_{\mathrm{A}} \mathrm{S}_{\mathrm{D}}$} & $4 / 4 \mathrm{cs}$ & $1 / 4$ & 4/411 & $0 / 4$ & $4 / 4 \mathrm{cs}$ & $4 / 4$ & 4/411 & $0 / 4$ & $4 / 4 \mathrm{cs}$ & $4 / 4$ & 4/411 & $0 / 4$ \\
\hline & $5 / 5 \mathrm{cs}$ & $0 / 5$ & $5 / 511$ & $0 / 5$ & $5 / 5 \mathrm{cs}$ & $5 / 5$ & $5 / 511$ & $1 / 5$ & $5 / 5 \mathrm{cs}$ & $5 / 5$ & $5 / 511$ & $1 / 5$ \\
\hline
\end{tabular}

a Susceptible pepper genotype = Capsicum annuum cv. NuMex RNaky; resistant pepper genotype =C. chinense PI 159234 .

b TSWV parental isolates D, A, and their reassortant progeny isolates. First line of data for each viral genotype is from experiment 1 , second from experiment 2 .

${ }^{c}$ Response observed on inoculated (I) and uninoculated (U) leaves of seedlings mechanically inoculated with TSWV.

${ }^{\mathrm{d}}$ cs = chlorotic spots; 11 = local lesions; $(\mathrm{)}$ = number of plants that died after a severe systemic infection.

e Bold entries indicate viral genotypes that systemically infected the resistant pepper genotype, all of which contain the $\mathrm{S}$ RNA from isolate A.

${ }^{\mathrm{f}} \mathrm{ns}=$ necrotic spots. 
seedlings at the two-true-leaf stage. Seedlings were dusted with Carborundum powder and both true leaves were inoculated twice, 3 days apart, with inoculum prepared by homogenizing systemically infected leaves with cold $0.1 \mathrm{M}$ phosphate buffer, $\mathrm{pH}$ 7.0, containing 0.01 M sodium sulfite. After each inoculation, plants were rinsed with water, maintained in a greenhouse with a controlled temperature of $22^{\circ} \mathrm{C}$, and checked daily between 5 and 45 dpi for symptom development.

TSWV-GT was used to screen the $($ NuMex RNaky $\times$ PI 159234) $F_{3}$ families prepared as above, except inoculum was increased on $N$. benthamiana. Due to sterility in the interspecific comparative mapping population, only $48 / 75 \mathrm{~F}_{3}$ families were available with at least 12 plants per family. $F_{3}$ plants were grown for 8 weeks, then held in the dark for a day preceding inoculation, shaded immediately prior to inoculation, and cut back. The youngest pair of fully expanded leaves that remained after pruning was mechanically inoculated. Fresh inoculum was prepared for every 75 to 100 plants. Eleven days later, all new growth was reinoculated. Each plant was monitored for $109 \mathrm{dpi}$ and scored for resistance or susceptibility. $F_{3}$ families were classified into five groups (asymptomatic, local necrosis, systemic necrosis with pinpoint necrotic lesions, systemic necrosis without pinpoint lesions, mosaic without necrosis) to infer $F_{2}$ genotypes at the $T s w$ locus.

In all populations and parental genotypes screened, plants with no symptoms, or with local necrotic lesions that appeared 4 to $7 \mathrm{dpi}$, were considered resistant. Plants that developed systemic mosaic or systemic necrosis that did not include pinpoint necrotic lesions were scored as susceptible.

\section{Tagging $T s w$ and mapping the Q-06 270 amplification product, $S w-5$ homologues, and $T s w$.}

DNA samples from two TSWV-resistant $\mathrm{BC}_{4} \mathrm{~F}_{1}$ plants, one each from the Cuby and Spartacus backgrounds, together with the corresponding susceptible recurrent parents, were extracted from young leaves as described in Prince et al. (1997) and screened with 400 decanucleotide primers. Pepper DNA $(25 \mathrm{ng})$ was used as a template for polymerase chain reaction (PCR) amplification with RAPD kits A-C and J-U (Operon Technologies, Alameda, CA) and kits 1-5 (Advanced Biotechnologies, Leatherhead, UK). For PCR, 1 U of Biotaq DNA Polymerase (Bioprobe Systems, Montreuil Sous Bois, France) was used in a total volume of $15 \mu \mathrm{l}$. Amplifications were performed in a PTC-100 thermocycler (MJ Research, Incline Village, NV) as described by Paran et al. (1991). Markers that showed differential patterns in the resistant and susceptible samples were re-screened on a larger population of $116 \mathrm{BC}_{4} \mathrm{~F}_{1}$ plants that had also been inoculated with TSWV. Only one cosegregated with resistance so this population was used to estimate the genetic distance between Tsw and the locus detected by primer Q-06 270 .

This same primer was used to amplify 64 DNA samples from the $\left(\right.$ NuMex RNaky $\times$ PI 159234) $\mathrm{F}_{2}$ mapping population (Livingstone et al 1999) to generate Q-06 270 genotypes. For mapping $S w-5$ homologues, filters were prepared as described in Livingstone et al. (1999) and hybridized with a clone of the $S w-5$ cDNA kindly provided by S. H. Brommenschenkel and S. D. Tanksley. Segregation analysis for molecular marker data and the 39 / 48 inferred $F_{2}$ genotypes for $T s w$ was performed with the Mapmaker/Exp v3.0b program (Lincoln et al.
1993) as described by Livingstone et al. (1999). The location of $T s w$ was found with the "near" command at a LOD > 2.5.

\section{Viral genome reassortment studies.}

TSWV-A (Regular 2A), provided by J. Cho, University of Hawaii, was isolated from a homozygous $\mathrm{Sw}-5$ tomato cultivar. To create viral reassortants (Qiu et al. 1998), TSWV-A was coinfected on $N$. benthamiana with TSWV-D, an isolate from The Netherlands recovered from Dahlia that is suppressed by $S w-5$ (K. Hoffmann, W. Qiu, and J. Moyer, unpublished). Parental isolates were maintained in Emilia sonchifolia in the greenhouse and stored in systemically infected $N$. benthamiana tissue at $-80^{\circ} \mathrm{C}$. Systemically infected leaves were then used to inoculate N. tabacum cv. Burley 21. Single local lesions were transferred at least three times in $N$. tabacum cv. Burley 21 to select and segregate putative reassortants according to their local lesion type, shape, and time of appearance. Putative reassortants were then inoculated on $N$. benthamiana for extraction of total RNA (Qiu et al. 1998).

To determine the contributing parental isolate of each genome segment in the putative reassortants, genome markers located on the L, M, and S RNA were used as described by Qiu et al. (1998). Prior to mechanical inoculation of pepper, inoculum was transferred once to N. benthamiana. PI 159234 and NuMex RNaky were grown in a greenhouse in Raleigh, $\mathrm{NC}$, at 20 to $30^{\circ} \mathrm{C}$ and inoculated at the two-true-leaf stage. Symptoms were monitored at 2-day intervals after first appearance and recorded up to $28 \mathrm{dpi}$. Presence or absence of systemic symptoms at the end of the experimental period was confirmed by inoculation of $N$. benthamiana with upper noninoculated pepper leaves. Due to the rapid development of necrosis on very small plants very soon after inoculation, it was not possible to isolate total RNA to confirm the composition of the isolates directly from the necrotic leaf tissue of the pepper plants or to use systemically infected pepper leaves for back-inoculation.

\section{NOTE ADDED IN PROOF}

The CAPS marker reported by Moury et al. (2000) to be $<1 \mathrm{cM}$ from $T s w$ maps $2 \mathrm{cM}$ proximal to CD72 at LOD $>8$.

\section{ACKNOWLEDGMENTS}

We thank P. Himmel and J. Cho for providing inoculum, S. H. Brommenschenkel and S. D. Tanksley for unpublished data and access to the $S w-5$ clone, C. Lewis for hybridizing pepper filters with the $S w-5$ clone, J. P. Jantz, G. Moriarty, and B. Shipman for technical assistance, and M. M. Cadle and L. G. Landry for critical review of the manuscript. This work was supported in part by USDA NRICGP Award Nos. 9137300-6564 and 94-37300-0333, BARD Award IS-2389-94 and the California Pepper Improvement Foundation/California Pepper Commission. K. D. L. and R. C. G. were supported by a DOE/NSF/USDA grant to the Research Training Group in Molecular Mechanisms of Plant Processes and gifts from Novartis, Seminis Vegetable Seeds, M. Lavallard, and C. M. Werly.

\section{LITERATURE CITED}

Antignus, Y., Lapidot, M., Ganaim, N., Cohen, J., Lachman, O., Pearlsman, M., Raccah, B., and Gera, A. 1997. Biological and molecular characterization of tomato spotted wilt virus in Israel. Phytoparasitica 25:319-330.

Bent, A. F., Kunkel, B. N., Dahlbeck, D., Brown, K. L., Schmidt, R., 
Giraudat, J., Leung, J., and Staskawicz, B. J. 1994. Rps2 of Arabidopsis thaliana $\mathrm{L}$., a leucine-rich repeat class of plant disease resistance genes. Science 265:1856-1860.

Black, L. L., Hobbs, H. A., and Gatti, J. M., Jr. 1991, Tomato spotted wilt virus resistance in C. chinense PI152225 and 159236. Plant Dis. 75:863.

Boiteux, L. S. 1995. Allelic relationships between genes for resistance to tomato spotted wilt tospovirus in Capsicum chinense. Theor. Appl. Genet. 90:146-149.

Boiteux, L. S., Nagata, T., Dutra, P. W., and Fonseca, M. E. N. 1993. Sources of resistance to tomato spotted wilt virus (TSWV) in cultivated and wild species of Capsicum. Euphytica 67:89-94.

Brommenschenkel, S. H., and Tanksley, S. D. 1997. Map-based cloning of the tomato genomic region that spans the $S w-5$ tospovirus resistance gene in tomato. Mol. Gen. Genet. 256:121-126.

Cho, J. J., Custer, D. M., Brommenschenkel, S. H., and Tanksley, S. D. 1996. Conventional breeding: Host-plant resistance and the use of molecular markers to develop resistance to tomato spotted wilt virus. Acta Hortic. 431:367-378.

Edwardson, J. R., and Christie, R. G. 1997. Viruses infecting peppers and other solanaceous crops. University of Florida, Gainesville.

El-Kharbotly, A., Leonards-Schippers, C., Huigen, D. J., Jacobsen, E., Pereira, A., Stiekema, W. J., Salamini, F., and Gebhardt, C. 1994. Segregation analysis and RFLP mapping of the $R 1$ and $R 3$ alleles conferring race-specific resistance to Phytophthora infestans in progeny of dihaploid potato parents. Mol. Gen. Genet. 242:749-754.

El-Kharbotly, A., Palomino-Sánchez, C., Salamini, F., Jacobsen, E., and Gebhardt, C. 1996. $R 6$ and $R 7$ alleles of potato conferring racespecific resistance to Phytophthora infestans (Mont.) de Bary identified genetic loci clustering with the $R 3$ locus on chromosome XI. Theor. Appl. Genet. 92:880-884.

Ellis, J. G., Lawrence, G. J., Luck, J. E., and Dodds, P. N. 1999. Identification of regions in alleles of the flax rust resistance gene $L$ that determined differences in gene-for-gene specificity. Plant Cell 11:495506.

Finlay, K. W. 1953. Inheritance of spotted wilt resistance in the tomato. II. Five genes controlling spotted wilt resistance in four tomato types. Aust. J. Sci. Res. 6:153-163.

Gale, M. D., and Devos, K. M. 1998. Comparative genetics in the grasses. Proc. Natl. Acad. Sci. USA 95:1971-1974.

Grube, R. C., Blauth, J. R., Arnedo Andres, M. S., Caranta, C., and, Jahn, M. K. Identification and comparative mapping of a dominant potyvirus resistance gene cluster in Capsicum. Theor. Appl. Genet. (In press.)

Grube, R. C., Radwanski, E. R., and Jahn, M. K. Comparative genetics of disease resistance within the Solanaceae. Genetics (In press.)

Hammond-Kosack, K. E., and Jones, J. D. G. 1997. Plant disease resistance genes. Annu. Rev. Plant Physiol. Plant Mol. Biol. 48:575-607.

Hammond-Kosack, K. E., Tang, S. J., Harrison, K., and Jones, J. D. G. 1998. The tomato $C f-9$ disease resistance gene functions in tobacco and potato to confer responsiveness to the fungal avirulence gene product Avr9. Plant Cell 10:1251-1266.

Hartl, L., Weiss, H., Zeller, F. J., and Jahoor, A. 1993. Use of RFLP markers for the identification of alleles of the Pm3 locus conferring powdery mildew resistance in wheat (Triticum aestivum). Theor. Appl. Genet. 86:959-963.

Hehl, R., Faurie, E., Hesselbach, J., Salamini, F., Whitham, S., Baker, B., and Gebhardt, C. 1999. TMV resistance gene $N$ homologues are linked to Synchytrium endobioticum resistance in potato. Theor. Appl. Genet. 98:379-386.

Holmes, F. O. 1948. Resistance to spotted wilt in tomato. Phytopathology $38: 467-473$.

Innes, R., 1998. Genetic dissection of R gene signal transduction pathways. Curr. Opin. Plant Biol. 1:299-304.

Johal, G. S., and Briggs, S. P. 1992. Reductase activity encoded by the $\mathrm{Hml}$ disease resistance gene in maize. Science 258:985-987.

Kyle, M. M., and Palloix, A. 1997. Proposed revision of nomenclature for potyvirus resistance genes in Capsicum. Euphytica 97:183-188.

Li, X., van Eck, H. J., van der Voort, J. N. A. M. R., Huigen, D.-J., Stam, P., and Jacobsen, E. 1998. Autotetraploids and genetic mapping using common AFLP markers: The $R 2$ allele conferring resistance to Phytophthora infestans mapped on potato chromosome 4. Theor. Appl. Genet. 96:1121-1128.

Lincoln, S. E., Daly, M. J., and Lander, E. S. 1993. Construction of a genetic linkage map with Mapmaker/Exp v3.0: A tutorial and reference manual. Whitehead Inst. Tech. Rep., Cambridge, MA.

Livingstone, K. D., Lackney, V. K., Blauth, J. R., van Wijk, R., and Jahn, M. K. 1999. Genome mapping in Capsicum and the evolution of genome structure in the Solanaceae. Genetics 152:1183-1202.

Loh, Y. T., and Martin, G. B. 1995. The disease resistance gene Pto and the fenthion-sensitivity gene Fen encode closely related functional protein-kinases. Proc. Natl. Acad. Sci. USA 92:4181-4184.

Martin, G. B., Brommenschenkel, S. H., Chunwongse, J., Frary, A., Ganal, M. W., Spivey, R., Wu, T., Earle, E. D., and Tanksley, S. D. 1993. Map-based cloning of a protein kinase gene conferring disease resistance in tomato. Science 262:1432-1436.

Meksem, K., Leister, D., Peleman, J., Zabeau, M., Salamini, F., and Gebhardt, C. 1995. A high-resolution map of the vicinity of the Rl locus on chromosome $\mathrm{V}$ of potato based in RFLP and AFLP markers. Mol. Gen. Genet. 249:74-81.

Meshi, T., Motoyoshi, F., Adachi, A., Watanabe, Y., Takamatsu, N., and Okada, Y. 1988. Two concomitant base substitutions in the putative replicase genes of tobacco mosaic virus confer the ability to overcome the effects of tomato resistance gene Tm-1. EMBO J. 7:1575-1581.

Meshi, T., Motoyoshi, F., Maeda, T., Yoshiwoka, S., Watanabe, H., and Okada, Y. 1989. Mutations in the tobacco mosaic virus 30-kDa protein gene overcome Tm-2 resistance in tomato. Plant Cell 1:515-522.

Meyers, B. C., Chin, D. B., Shen, K. A., Sivaramakrishnan, S., Lavelle, D. O., Zhang, Z., and Michelmore, R. W. 1998. The major resistance gene cluster in lettuce is highly duplicated and spans several megabases. Plant Cell 10:1817-1832.

Michelmore, R. W., and Meyers, B. C. 1998. Clusters of resistance genes in plants evolve by divergent selection and a birth-and-death process. Genome Res. 8:1113-1130.

Milligan, S. B., Bodeau, J., Yaghoobi, J., Kaloshian, I., Zabel, P., and Williamson, V. M. 1998. The root knot nematode resistance gene $M i$ from tomato is a member of the leucine-zipper, nucleotide binding, leucine-rich repeat family of plant genes. Plant Cell 10:1307-1319.

Moreau, P., Thoquet, P., Olivier, J., Laterrot, H., and Grimsley, N. 1998. Genetic mapping of $P h-2$, a single locus controlling partial resistance to Phytophthora infestans in tomato. Mol. Plant-Microbe Interact. 11: 259-269.

Moury, B., Pflieger, S., Blattes, A., Lefebvre, V., and Palloix, A. 2000. A CAPS marker to assist selection of tomato spotted wilt virus (TSWV) resistance in pepper. Genome 43:137-142.

Moury, B., Palloix, A., Selassie, K. G., and Marchoux, G. 1997. Hypersensitive resistance to tomato spotted wilt virus in three Capsicum chinense accessions is controlled by a single gene and is overcome by virulent strains. Euphytica 94:45-52.

Moury, B., Selassie, K. G., Marchoux, G., Daubèze, A.-M., and Palloix, A. 1998. High temperature effects on hypersensitive resistance to tomato spotted wilt tospovirus (TSWV) in pepper (Capsicum chinense Jacq.). Eur. J. Plant Pathol. 104:489-498.

Multani, D. S., Meeley, R. B., Paterson, A. H., Gray, J., Briggs, S. O., and Johal, G. S. 1998. Plant-pathogen evolution: Molecular basis for the origin of a fungal disease in maize. Proc. Natl. Acad. Sci. USA 95: 1686-1691.

Munford, R. A., Barker, I., and Wood, K. R. 1996. The biology of the tospoviruses. Ann. Appl. Biol. 128:159-183.

Ohmori, T., Murata, M., and Motoyoshi, F. 1998. Characterization of disease resistance gene-like sequences in near-isogenic lines of tomato. Theor. Appl. Genet. 96:331-338.

Padgett, H. S., and Beachy, R. N. 1993. Analysis of a tobacco mosaic virus strain capable of overcoming $N$ gene-mediated resistance. Plant Cell 5:577-586.

Paran, I., Kesseli, R., and Michelmore, R. W. 1991. Identification of restriction fragment polymorphism and random amplified polymorphic DNA markers linked to downy mildew resistance genes in lettuce using near-isogenic lines. Genome 34:1021-1027.

Parker, J. E., Coleman, M. J., Szabo, V., Frost, L. N., Schmidt, R., van der Biezen, E. A., Moores, T., Dean, C., Daniels, M. J., and Jones, J. D. 1997. The Arabidopsis downy mildew resistance gene Rpp5 shares similarity to the Toll and interleukin-1 receptors with $N$ and $L 6$. Plant Cell 9:879-894.

Parniske, M., and Jones, J. D. 1999. Recombination between diverged clusters of the tomato $C f-9$ plant disease resistance gene family. Proc. Natl. Acad. Sci. USA 96: 5850-5855.

Pierce, L. C. 1971. Linkage tests with $P h$ conditioning resistance to race 
0, Phytophthora infestans. Rep. Tomato Genet. Coop. 21:30.

Prince, J. P., Zhang, Y., Radwanski, E. R., and Kyle, M. M. 1997. A versatile and high-yielding protocol for the preparation of genomic DNA from Capsicum spp. (pepper). HortScience 32:937-939.

Qiu, W. P., Geske, S. M., Hickey, C. M., and Moyer, J. W. 1998. Tomato spotted wilt tospovirus genome reassortment and genome segmentspecific adaptation. Virology 244:186-194.

Rommens, C. M. T., Salmeron, J. M., Oldroyd, C. E. D., and Staskawicz, B. J. 1995. Intergeneric transfer and functional expression of the tomato disease resistance gene Pto. Plant Cell 7:1537-1544.

Ronald, P. 1998. Resistance gene evolution. Curr. Opin. Plant Biol. 1: 294-298.

Roselló, S., Díez, M. J., and Nuez, F. 1996. Viral diseases causing the greatest losses to the tomato crop. I. The tomato spotted wilt virus - a review. Sci. Hortic. 67:117-150.

Roselló, S., Díez, M. J., and Nuez, F. 1998. Genetics of tomato spotted wilt virus resistance coming from Lycopersicon peruvianum. Eur. J. Plant Pathol. 104:499-509.

Rossi, M., Goggin, F. L., Milligan, S. B., Kaloshian, I., Ullman, D. E., and Williamson, V. M. 1998. The nematode resistance gene $M i$ of tomato confers resistance against the potato aphid. Proc. Natl. Acad. Sci. USA 95:9750-9754.

Salmeron, J. M., Oldroyd, G. E. D., Rommens, C. M. T., Scofield, S. R. Kim, H. S., Lavelle, D. T., Dahlbeck, D., and Staskawicz, B. J. 1996. Tomato Prf is a member of the leucine-rich repeat class of plant disease resistance genes and lies embedded within the Pto kinase gene cluster. Cell 86:123-133.

Samuel, G., Bald, J. G., and Pitman, H. A. 1930. Spotted wilt of tomatoes. Aust. Con. Sci. Ind. Res. Bull. 44

Schönfeld, M., Ragni, A., Fischbeck, G., and Jahoor, A. 1996. RFLP mapping of three new loci for resistance genes to powdery mildew (Erysiphe graminis f. sp. hordei) in barley. Theor. Appl. Genet. 93:48 56.

Song, W. Y., Wang, G. L., Chen, L. L., Kim, H. S., Pi, L. Y., Holsten, T., Gardner, J., Wang, B., Zhai, W. X., Zhu, L. H., Fauquet, C., and Ronald, P. 1995. A receptor kinase-like protein encoded by the rice disease resistance gene, $X a 21$. Science 270:1804-1806.

Stevens, M. R., Scott, S. J., and Gergerich, R. C. 1992. Inheritance of a gene for resistance to tomato spotted wilt virus (TSWV) from $L y$ copersicon esculentum Mill. Euphytica 59:9-17.

Stevens, M. R., Lamb, E. M., and Rhoads, D. D., 1995. Mapping the $S w-5$ locus for tomato spotted wilt virus resistance in tomatoes using RAPD and RFLP analyses. Theor. Appl. Genet. 90:451-456.
Tanksley, S. D., Ganal, M. W., Prince, J. P., de Vicente, M. C., Bonierbale, M. W., Broun, P., Fulton, T. M., Giovannoni, J. J., Grandillo, S., Martin, G. B., Messeguer, R., Miller, J. C., Miller, L., Paterson, A. H., Pineda, O., Röder, M. S., Wing, R. A., Wu, W., and Young, N. D. 1992. High density molecular linkage maps of the tomato and potato genomes. Genetics 132:1141-1160

Thilmony, R. L., Chen, Z. T., Bressan, R. A., and Martin, G. B. 1995. Expression of the tomato Pto gene in tobacco enhances resistance to Pseudomonas syringae pv. tabaci expressing Avrpto. Plant Cell 7: 1529-1536.

Thomas, C. M., Dixon, M. S., Parniske, M., Goldstein, C., and Jones, J. D. G. 1998. Genetics and molecular analysis of tomato $C f$ genes for resistance to Cladosporium fulvum. Phil. Trans. R. Soc. Lond. 353 1413-1424.

Thomas, C. M., Jones, D. A., Parniske, M., Harrison, K., Balint-Kurti, P. J., Hatzixanthis, K., and Jones, J. D. G. 1997. Characterization of the tomato $C f-4$ gene for resistance to Cladosporium fulvum identifies sequences that determine recognitional specificity in $C f-4$ and $C f-9$. Plant Cell 9:2209-2224.

Tommiska, T. J., Hämäläinen, J. H., Watanabe, K. N., and Valkonen, J. P. T. 1998. Mapping of the gene $N x_{p h u}$ that controls hypersensitive resistance to potato virus X in Solanum phureja lvP35. Theor. Appl. Genet. 96:840-843

van der Voort, J. R., Kanyuka, K., van der Vossen, E., Bendahmane, A. Moojiman, P., Klein-Lankhorst, R, Stiekema, W., Baulcombe, D., and Bakker, J. 1999. Tight physical linkage of the nematode resistance gene Gpa2 and the virus resistance gene $R x$ on a single segment introgressed from the wild species Solanum tuberosum subsp. andigena CPC 1673 into cultivated potato. Mol. Plant-Microbe Interact. 12: 197-206.

Watanabe, Y., Kishibayashi, N., Motoyoshi, F., and Okada, Y., 1987. Characterization of $T m-1$ gene action on replication of common isolates and a resistance-breaking isolate of TMV. Virology 161:527-532.

Whitham, S., Dinesh-Kumar, S. P., Choi, D., Hehl, R., Corr, C., and Baker, B. 1994. The product of the tobacco mosaic virus resistance gene $N$ : similarity to Toll and the Interleukin-1 receptor. Cell 78:11011115.

Whitham, S., McCormick, S., and Baker, B. 1996. The $N$ gene of tobacco confers resistance to tobacco mosaic virus in transgenic tomato. Proc. Natl. Acad. Sci. USA 93:8776-8781.

Yu, G. X., Bush, A. L., and Wise, R. P. 1996. Comparative mapping of homoeologous group 1 regions and genes for resistance to obligate biotrophs in Avena, Hordeum, and Zea mays. Genome 39:155-164. 